\title{
Commercial Buildings as Public Spaces
}

\author{
Gregorius Prasetyo Adhitama1 , Hisashi Komatsu² \\ ${ }^{1}$ Faculty of Art and Design, \\ Bandung Institute of Technology, Indonesia \\ ${ }^{2}$ Graduate School of Environmental Studies, \\ Nagoya University, Japan \\ prasetyoa@yahoo.com
}

\begin{abstract}
This research aims to verify the contribution of three commercial buildings in providing places for public in Bandung and Jakarta city in Indonesia. To achieve this goal, some field observations, interviews and evaluation of public activities at the buildings were conducted. The public uses and the ways the company manages the buildings that enable public activities were evaluated. The results of this research show that some types of public activities are identified. The types of the public activities are related to the ways the company manages the places and the physical characters of the places.
\end{abstract}

Keywords: commercial; buildings; public space

eISSN 2398-4279 @ 2018. The Authors. Published for AMER ABRA cE-Bs by e-International Publishing House, Ltd., UK. This is an open access article under the CC BY-NC-ND license (http://creativecommons.org/licenses/bync-nd/4.0/). Peer-review under responsibility of AMER (Association of Malaysian Environment-Behaviour Researchers), ABRA (Association of Behavioural Researchers on Asians) and cE-Bs (Centre for EnvironmentBehaviour Studies), Faculty of Architecture, Planning \& Surveying, Universiti Teknologi MARA, Malaysia.

DOI: https://doi.org/10.21834/ajqol.v3i10.95 


\subsection{Introduction}

Development of commercial buildings in cities in Indonesia has been characterizing the growth of the economy in the last two decades. More than 36.000 commercial buildings were raised in many places in line with the growth of the economy (Adhitama and Komatsu, 2013). Unfortunately, the growth of many areas in Indonesia is not managed appropriately. Government regulations concerning urban design are not developed well. The lacks of public space in many urban areas are also acknowledged. The commercial sectors keep developing their buildings without contributing adequate facilities to support public activities.

The combination of the weak governments, lack of urban design regulations and awareness of commercial sectors in providing public facilities becomes threats to many cities. Most of the companies only concern about how they facilitate their commercial business activities. By considering the large numbers of commercial buildings in many cities, with appropriate efforts, they may be able to contribute widely to facilitating public activities. So, it is important to understand how commercial buildings may contribute to facilitating public activities.

\subsection{Literature Review}

The relation among buildings and city life were analyzed by Aziz and Said (2011), Hanan (2012), Jalaladdini and Oktay (2013), Kurniawati (2012) and Nasution and Zahrah (2012). Rapoport (1977, p. 300) identifies boundaries, supportive facilities, rules of behavior, and relation to other places as the environment resources that enable activities in a place. The previous researches indicate the aspects should be evaluated to discover how certain activities occur. In the field of business and management, Thomas and Cross (2007) evaluated the role of corporations as agents in the place making through corporate social responsibility (CSR). They introduced the characters of organizations as place maker by analyzing the corporate culture, behaviors, values, visions, missions and priorities of companies. Nevertheless, the contribution of commercial buildings to provide space for public, especially in Indonesia, is less evaluated.

\subsection{Methodology}

This research aims to discover how commercial buildings contribute to providing space for public by investigating the public uses of three commercial buildings and the ways the company manages the places. The research was conducted by analyzing the occurred public activities in the relation to the physical setting and the rules as the environmental resources of the activities.

Three commercial buildings of a state-owned company were analyzed to achieve the goals of the research. The company runs its commercial business of postal, parcel and financial services. It was selected from the evaluation of eleven prominent companies in Indonesia and considered as one whose buildings with adequate characters in the relation to the objective of this research (Adhitama and Komatsu, 2014). The three buildings were 
different concerning physical characters and context in Jakarta city and Bandung city of Indonesia. Case 1 was a heritage building located in a governmental office area; Case 2 was also a heritage building located in a heritage service and trade area, and Case 3 was a modern building located in a new business area. In the cases 1 and 2 , the characters of the old buildings are preserved, meanwhile in the case 3 , the new corporate architectural design standard was fully applied. Besides, the three buildings were selected because they were considered represent the variety of places and conditions of the company's branches.

The analysis was focused on the public activities that were nothing to do with the commercial businesses of the company because they occurred beyond the public intentions in utilizing the commercial services offered by the company.

The data was collected mainly from the fields observations and interviews conducted at the three places. To identify the occurred activities, two fixed and one mobile camera was used to record the phenomena: (1) inside the buildings (the customer halls), (2) in front of the buildings to cover the sidewalk and front yard of the building. The data was collected by following the time cycle of company service hours to deliver a coherent data of public activities related to the company activities. Fields observations were conducted for three days between 10.00-11.00 and 14.00-15.00 each case in February to March 2013. The periods of observations were considered represented the two moments of service hours of the company (morning and afternoon) and the level of activity (peak-low hours). The observed activities and the environment resources were recorded and mapped.

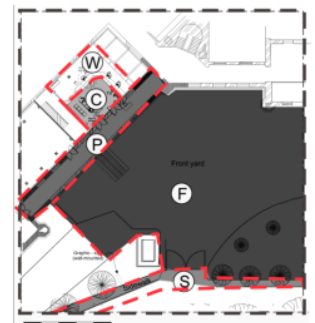

CASE 1

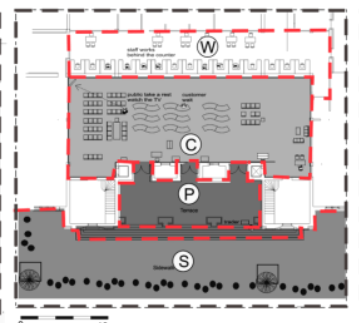

CASE 2

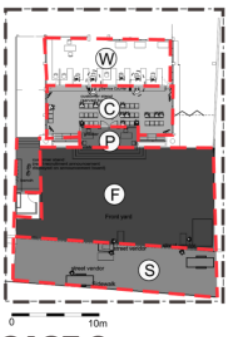

CASE 3

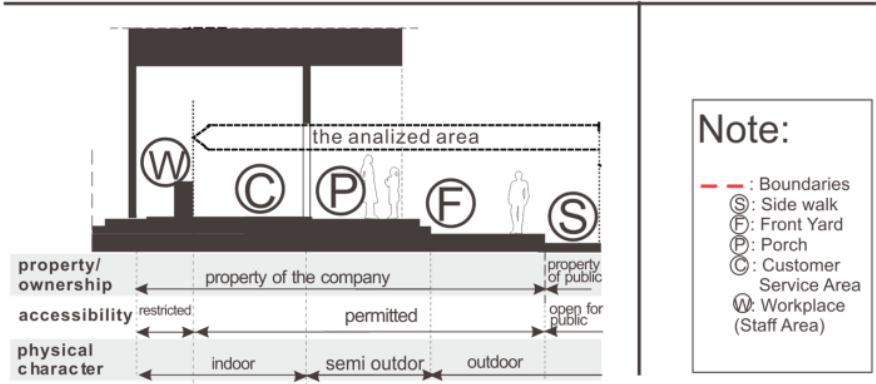

Figure 1: The Boundariesand the definitions of the analyzed areas (Source: Prepared by the author) 
Rules as resources that enable public activities were identified by interviewing six staffs (branch manager and security staff in each case) to understand how the company plays their role in supporting the activities. The rules and the roles of the company staffs in enforcing the rules were firstly informed by the staffs, and then this information was confirmed in the observations and by interviewing people who used the buildings. The identified rules of the activities were also considered as confirmation of the company policies and intentions.

The places investigated in this research were defined concerning the ownership, the accessibility and the physical characters of the places. By considering these aspects, the analyzed areas were defined as customer service halls, transition areas (porch and front yard) and public area (sidewalks in front of the buildings).

Each of the places was unique concerning the combination of the three attributes. For example, the sidewalk is an outdoor place, property of public so that public can access the place anytime. The sidewalk is different from the front yard concerning accessibility and ownership because the front yard is owned by the company and only can be accessed by public during the office hours. Figure 1 shows different characters combinations of ownership, the accessibility and the physical characters of each area.

\subsection{Findings and Discussions}

\section{The occurred activities}

Totally twelve types of activities are identified: Customer service, Student visit/study tours, Public visit/tour, People read the recruitment announcement, Philately Club Activity, Taking a rest, Playing chess, Philately on the sidewalk, Meeting/Talking, Street Education, Photography activity and Trading by street vendors.

Customer service is the activity that is related to the main business of the company. From the observations, it was identified that customer service was the most occurred activity. Customer service is a series of activities designed to enhance the level of customer satisfaction. Student visit/study tours activities identified in the observations were conducted by various groups of students. They were kindergarten, elementary, junior and senior high schools. They were mostly lead by a leader (teachers). During the observation periods, a company staff (the duty manager) guided the activity; more staffs guided the activities especially in the case of large groups ( 15 to 500 students). The student conducted the activity for the reasons of heritage learning (case $1 \& 2$ ) or to learn the way the company serves the customers (Case 1 and case 3 ). The activity was conducted in the outside and inside the buildings.

Various groups of people in the cases 1 and 2 conducted tourism activities. They visited the place for the reasons related to historical and heritage values of the places. Public also used some facilities of the three building to take a rest after doing some other activities that were not related to the commercial business of the company. Somehow, people took a rest at the terrace and front yard (sitting on the stairs or lower walls, chairs, and benches under the canopies of the buildings) and in the customer service halls while watching television mounted on the wall or ceiling. In the case of the activity occurred in the customer service 
hall, the employees let them use the facilities conveniently, even some friendly conversations occurred among the employee and public in these events. The Street education activity only occurred in the case 2 . The street education organized by a non-governmental organization led by an artist. They organized the activity in the afternoon. 40 street children were guided by six mentors learning some basic things such as drawing the environment and reading. They conducted the activity at the terrace and public area in front of the building by using stairs as stage and mat on the floors to sit. Trading activities were conducted by the public in the three cases. People mostly conducted these activities on the sidewalk in front of the buildings, but sometimes they occurred in the transition areas and the customer service hall. All of the activities were mapped to distinct the location and the environmental resources of the activities.

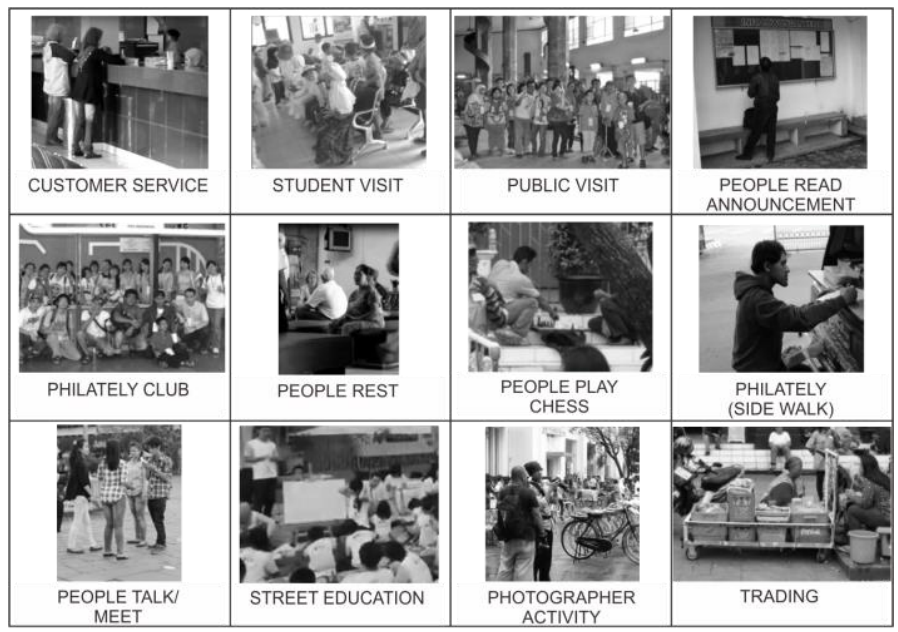

Figure 2: The activities identified in the three cases

(Source: Prepared by the author)

Figure 3, 4 and 5 summarize the occurred activities (types and amount of occurrences), the location, and the ownership of the places, accessibility, the physical characters of the places and the physical environment resources.

From the analysis, the environment resources of public activities at the three cases are identified. They comprise of boundaries, link to the adjacent spaces and the supporting facilities (benches, floors, walls, and shelters). 


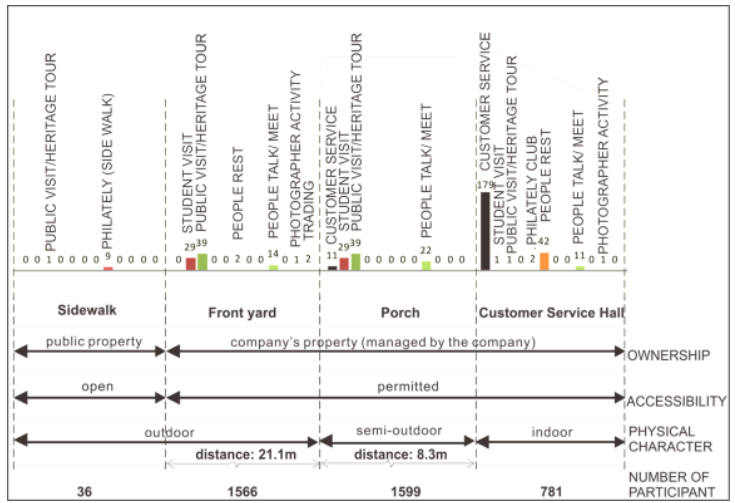

Figure 3: Summary of the phenomena in the case 1

(Source: Prepared by the author)

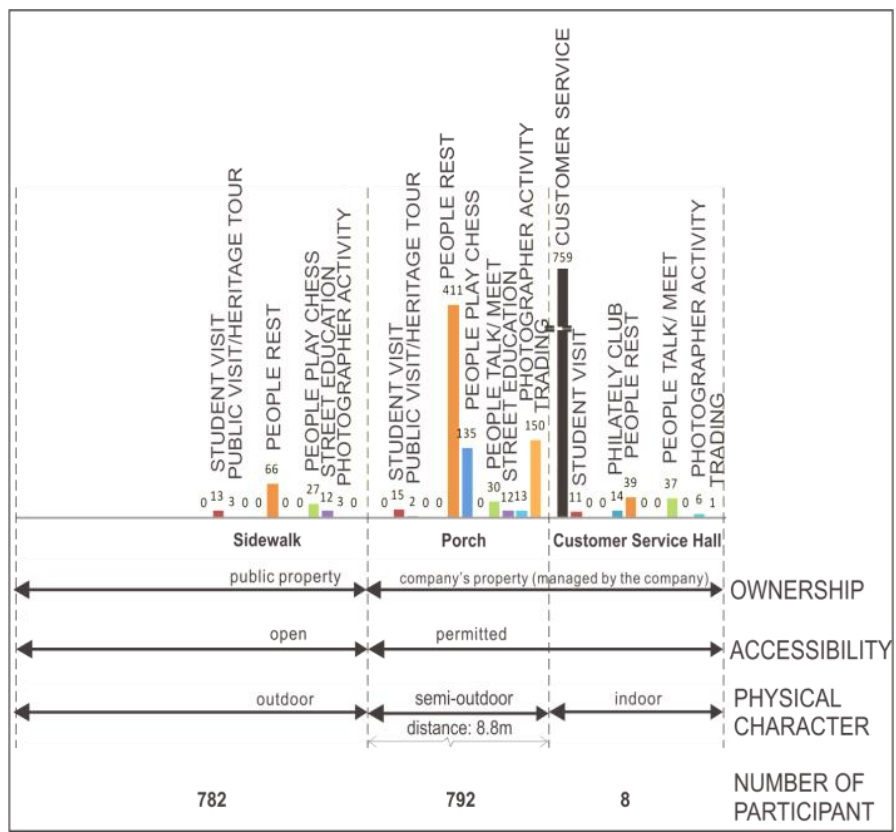

Figure 4: Summary of the phenomena in the case 2

(Source: Prepared by the author) 


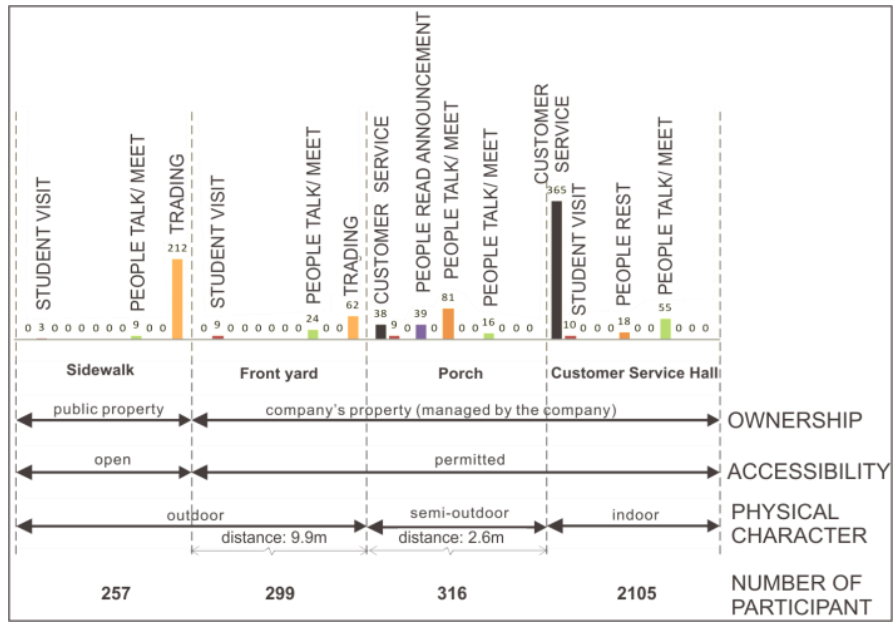

Figure 5: Summary of the phenomena in the case 3

(Source: Prepared by the author)

\section{The Public activities and the characters of places}

The findings show that some public activities occur in the observed areas of the three cases. Student visits, public tours, photography activities, sitting/taking a rest, meeting/talking, playing chess, street children education, reading the recruitment announcement, and trading are the public activities occur at the places. Among the activities, student visits, public tours, photography in the case 1 and 2 are the ones that relate to the original characters of the heritage buildings. People use the two buildings as the environment resources of their activities. The findings also show that public activities in the areas which are owned by the company (front yards of case 1 and 3 , porches and customer service halls of all cases) are more than in the public areas (sidewalk) concerning types and number of occurrences.

These indicate that there are more public activities in the areas owned by the company than in the public areas in front of the buildings. These also indicate that the front yards, porches, and the customer service halls are easy to be accessed by the public. Concerning the number of type of activity and occurrence, in general, there are more types of public activities in transition areas than in the customer service halls of the three cases. The findings show that more public activities occurred in the porches of case 2 and 3 . At the porch, there are sitting places and shelters. Sitting places can be steps of a stair, lower walls, benches, and chairs. The differences of the porches and the front yards are the availability of the sitting places and shelters. The shelters are roofs of the porches; they cover the areas from the heat of the sun. Meanwhile, in the case 1, the activities in the front yard are more than in the porch. The findings also show that the short distances of the places from the public areas, the availability of shelters and sitting facilities characterize the areas where more public activities occur. 
The company considers the social and cultural contributions as it was stated in the company's visions and missions statements. The company's visions and missions statements are inspiring the company staffs in managing the activities. It directs the company staffs in managing the operations including the operations of the three post office buildings. Besides, it was found that the socio-cultural contribution can be considered as the most important aspects in the relation between the company management and the community in general.

The identified public activities are not related to the commercial business of the company; however, the company allows the public activities. The security staffs manage the activities by monitoring and making sure that the public activities are not disturbing the commercial service. These all are the rule as the environment resource of the activities that are referring to the management of the branch office operations.

The findings of the analysis show that the company staffs of the three branch offices allow some public activities: sitting/taking a rest, meeting/talking and trading (all cases), street children education and playing chess (case 2). Meanwhile in some other public activities, the staffs allow and provide service: student visits (all cases), public heritage visits and photography activities (case 1 and 2). The staffs support or serve the public by providing guidance and some facilities such as spaces, tables, chairs and benches (Table 1).

The social and cultural visions of the company also enable the preservation of the two heritage buildings (cases 1 and 2). The original characters of heritage buildings that were preserved (cases 1 and 2) equip three public activities (Student visits, public heritage visits, and photography). The findings from the analysis also show that the company staffs (who have the right and take responsibility to manage the places within the properties of the company) play the role in defining rules of activities. Meanwhile, public consider the places in the front yards, porches, and customer service are acceptable for conducting the activities. At the same time, the elements of the buildings are considered supporting the activities.

Table 1: The roles of company in managing the public activities

\begin{tabular}{|c|c|c|c|c|c|c|}
\hline & \multicolumn{2}{|c|}{ Case 1} & \multicolumn{2}{|c|}{ Case 2} & \multicolumn{2}{|c|}{ Case 3} \\
\hline & $\begin{array}{c}\text { Company } \\
\text { allows the } \\
\text { activity }\end{array}$ & $\begin{array}{c}\text { Company } \\
\text { serves public in } \\
\text { conducting } \\
\text { activity }\end{array}$ & $\begin{array}{c}\text { Company } \\
\text { allows the } \\
\text { activity }\end{array}$ & $\begin{array}{c}\text { Company } \\
\text { serves public } \\
\text { in conducting } \\
\text { activity }\end{array}$ & $\begin{array}{c}\text { Company } \\
\text { allows the } \\
\text { activity }\end{array}$ & $\begin{array}{c}\text { Company } \\
\text { serves public } \\
\text { in conducting } \\
\text { activity }\end{array}$ \\
\hline Students visits/ study tours & o & 0 & 0 & 0 & 0 & o \\
\hline Public visits (heritage tour) & o & 0 & 0 & 0 & & \\
\hline Photographers (club) activities & 0 & 0 & 0 & 0 & & \\
\hline Sitting/ Taking a rest & 0 & $x$ & 0 & $x$ & $\circ$ & $x$ \\
\hline Meeting / Talking & 0 & $x$ & 0 & $x$ & o & $x$ \\
\hline Reading Recruitement Announcement & & - & 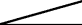 & 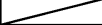 & 0 & 0 \\
\hline Playing chess & & - & 0 & $x$ & & \\
\hline Street Education & 2 & 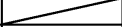 & 0 & $x$ & & \\
\hline Trading & 0 & $x$ & 0 & $x$ & 0 & $x$ \\
\hline
\end{tabular}

(Source: Prepared by the author)

\subsection{Conclusion}

\section{The corporate buildings and the public activities}

This research aims to discover how buildings contribute to providing space for public. In all 
cases, more public activities occur in the transition areas (front yards or porches) than the other areas including public areas (sidewalks) in front of the three buildings. Besides, the findings indicate that the spatial arrangements ease public to access and use facilities in those areas.

The company staffs also allow the spaces and facilities that are designed to support the customer services for public use. The availability of the company's properties for public uses and the commercial services are considered as the embodiment of the policies of the company stated in the vision and missions statements of the state-owned enterprise.

The findings of this research disclosure the possibilities of the company's buildings to contribute to the public on a daily basis. The spatial arrangements that ease public accessibility and the available facilities (space, shelters, and sitting facilities) may equip public activities. With congruent rules defined by the company, this can be considered the contribution of the buildings to public beyond the commercial business of the company.

\section{Contribution to knowledge and design practice}

The previous researches are focused on the relation of buildings and public activities. Therefore, problems of how the commercial buildings contribute to providing public space were unsolved. By focusing on the public activities at the commercial buildings, the results of this research may contribute to filling the knowledge gap.

The findings of this research lead to suggestions for companies and designers to concern on the public accessibility and to provide appropriate facilities for public uses such as shelters and sitting facilities. The result of this research delivers insights of how commercial buildings should be developed and managed to contribute to facilitating public activities. The condition may be different from other countries with the different culture or different nature of companies. Besides, the relations among the identified activities are not analyzed in this research. It can be the next research agenda that will be able to be conducted by considering the local context and by referring some previous researches cited in this paper.

\section{Acknowledgement}

The authors would like to express their great appreciation to the management of the Institut Teknologi Bandung (ITB) for providing the funding for this research.

\section{References}

Adhitama, Gregorius Prasetyo, \& Komatsu, Hisashi. (2013). Potential Influence of Indonesian Corporate Architectural Design (CorpAD) on Character of Place, Journal of Architecture and Planning (Transactions of AlJ) Vol. 78, No. 692, 2109-2118.

Adhitama, Gregorius Prasetyo, \& Komatsu, Hisashi. (2014). Application of an Indonesian Corporate Architectural Design (CorpAD) in Relation to the Local Characters of Place, Journal of Architecture and Planning (Transactions of AlJ) Vol. 79, No. 701, 1541-1551. 
Adhitama, G.P., \& Komatsu, H. / Asian Journal of Quality of Life (AjQoL), 3(10)) Mar / Apr 2018 (p.21-30)

Rapoport, Amos. (1977). Human Aspects of Urban Form. Towards a Man-Environment Approach to Urban Form and Design. New York: Pergamon Press.

Thomas, D.F, \& Cross, J., E. (2007). Organization as Place Builder, Journal of Behavior and Applied Management, Sept., Vol. 9, No. 1. 